\title{
Research on College Physical Education Reform Method based on Multiple Intelligences Theory
}

\author{
Ping Luo* \\ Yichun Vocational Technology College, Yichun 336000, China \\ *nior_0417@sina.com
}

\begin{abstract}
With the development of the times, people put forward higher and higher requirements for teaching, as well as physical education "Multiple Intelligences Theory" is applied in teaching reform in many fields. Multiple intelligences theory also plays a key role in sports teaching reform and promotes the development of sports teaching reform. The application of Multiple Intelligences Theory in physical education makes up for many shortcomings in traditional physical education. The teaching of eight kinds of intelligent organization courses is not only consistent with the spirit of quality education, but also aims to build a new physical education model suitable for students' comprehensive development in view of the shortcomings of traditional physical education and the needs of the times. Combining the characteristics of physical education teaching and the actual situation of students, it discusses how to apply Multiple Intelligences Theory to cultivate students' comprehensive intelligence in school physical education, in order to provide theoretical reference for physical education teaching reform.
\end{abstract}

Keywords: Multiple Intelligences Theory; College Sports; Teaching Reform.

\section{Introduction}

Multiple intelligences theory is a theory put forward by Howard Gardner, a psychological developmental scientist at Harvard University, in his book the architecture of intelligence published in 1983. This theory has a strong impact on the traditional teaching concept. It breaks two basic assumptions of the traditional intelligence theory: first, the human cognitive process is unified. Second, if a set of quantifiable intelligence indicators can accurately describe everyone [1]. Multiple Intelligences Theory holds that there are differences in cognitive ability among individuals, and points out that everyone is unique and has different and diversified development potentials. However, the teaching materials and teaching methods used in traditional education obviously cannot make students with different mental abilities achieve good learning results, and the unified teaching evaluation model is not conducive to the development of students, and the unified teaching evaluation is biased in distinguishing students [2]. College sports is the advanced stage of school sports, and it is also the foundation of mass sports and competitive sports. Especially under the guidance of the new concept of "health first" in the new century, College sports teaching has greatly promoted "sunshine sports" and the launch of the "National Fitness Campaign". The Multiple Intelligences Theory provides a new theoretical basis for China's College Physical Education Reform and development [3]. College sports plays an important role in the cultivation of talents in higher education. It is an important aspect of comprehensively implementing the party's and national education policies. Sports undertakes the tasks of strengthening physique and improving will and morality in the education of educating people. It is an indispensable part of Comprehensively Strengthening Quality Education. How to cultivate excellent talents with strong physique and allround development, to adapt to social development has become a top priority [4]. This paper puts forward some views on the reform of college sports teaching through multiple intelligences theory. 


\section{The Concept of Multiple Intelligences Theory and the Disadvantages of Traditional Physical Education}

\subsection{Educational Philosophy of Multiple Intelligences Theory}

The purpose of Multiple Intelligences Theory is to study the multiple structure of human intelligence function, create an open education system, and promote the comprehensive and full development of human mind. After more than 20 years of theoretical and practical research and development, it has aroused enthusiastic response from the global educational and psychological circles. This theory has been called the greatest educational theoretical discovery in the 20th century by many schools and educational institutions in countries and Europe [5]. Howard Gardner believes that the so-called intelligence is "the kind of ability that humans show in the process of solving problems and creating products." According to this definition of intelligence, Gardner proposed Multiple Intelligences Theory. These intelligences can be divided into eight categories: language intelligence, mathematical logic intelligence, visual space intelligence, body movement intelligence, music intelligence, interpersonal intelligence, and self-awareness intelligence. And natural intelligence [6].

Multiple intelligence theory extends people's vision of intelligence to an unprecedented range. The main points of view include the following aspects: first, everyone has these eight kinds of intelligence at the same time. Multiple intelligences theory is not a type theory, that is, to determine which type of intelligence a person's intelligence conforms to, but a cognitive function theory. Secondly, these eight intelligences are interrelated, and there is usually one primary or secondary intelligence. Third, it is possible for most people to develop any kind of intelligence to a satisfactory level. Fourth, every kind of intelligence has many ways of expression, and students' multiple intelligences can be cultivated in the teaching process of a certain course [7].

\subsection{Disadvantages Existing in Traditional Physical Education Teaching in Colleges and Universities}

The overall goal of traditional physical education is relatively general, while the specific goals that dominate school physical education are relatively narrow. The misconduct of the micro goals is mainly manifested in the following aspects: First, the emphasis is placed on taking the test and the students' physical and mental needs are ignored. Second, physical education is only suitable for a small number of students and ignores the fitness needs of most students. Third, the emphasis on basic skills teaching, while ignoring the teaching of mental health, common sense of health care and sports culture knowledge [8].

College sports teaching takes unified basketball, volleyball, football, track and field, aerobics and other teaching contents, and has unified syllabus and standards. The teaching contents are competitive sports, which are boring and single in form, which is not conducive to the formation of students' lifelong sports consciousness. In addition, it only focuses on making students master a certain sports skill, ignores the cultivation of students' innovative ability, and does not consider the cultivation of students' musical intelligence, spatial intelligence, interpersonal intelligence, self-cognitive intelligence, etc.

At present, physical education is a "unified system" education, and the basic point of this "unified system" education is to believe that everyone should be treated the same, learn the same courses in the same way, and evaluate the learning results in the same way. But in fact, every student's physicalkinesthetic intelligence and spatial intelligence are different, and adopting the "unified system" education can't aim at individual differences and teach students in accordance with their aptitude. As a result, some students keep repeating at the original level, while others can't master the teaching content.

Traditional physical education teaching evaluation is a "unified" evaluation centered on test scores. It aims to classify, rank, and screen students to discover their shortcomings. This so-called "unified" evaluation will not only dampen the enthusiasm and initiative of students, but also is not conducive 
to the healthy development of students. Therefore, College sports teaching should establish a scientific curriculum evaluation system to prevent one-sided teaching evaluation. It is necessary to pay attention to result evaluation and technical evaluation as well as process evaluation; it is necessary to carry out static evaluation according to fixed standards and principles, and to carry out dynamic evaluation according to the situation of Teaching Reform. To finally promote the continuous development of students, promote the continuous improvement of teachers' teaching level, and promote the development and innovation of college sports courses.

\section{College Physical Education Reform based on Multiple Intelligences Theory}

\subsection{Constructing the Related Theories of Teaching Mode}

Multiple intelligences physical education teaching objectives include the formulation of intelligence objectives, cognitive objectives, skill objectives and emotional objectives, as shown in Table 1.

Table 1. Teaching goals of multiple intelligences

\begin{tabular}{|c|c|c|c|}
\hline \multicolumn{4}{|c|}{ Teaching objectives } \\
\hline Smart goal & Cognitive goal & Skill goal & Emotion goal \\
\hline $\begin{array}{l}\text { According to the } \\
\text { students' self- } \\
\text { cognition ability and } \\
\text { the teacher's } \\
\text { observation, find out } \\
\text { the students' } \\
\text { intellectual strengths } \\
\text { and conduct targeted } \\
\text { learning }\end{array}$ & $\begin{array}{l}\text { Master the essentials } \\
\text { of skills and } \\
\text { movements, and learn } \\
\text { to analyze the } \\
\text { essentials of } \\
\text { techniques. Flexible } \\
\text { motor skills } \\
\text { movements. Apply to } \\
\text { competition and } \\
\text { teaching practice }\end{array}$ & $\begin{array}{c}\text { Establish technical } \\
\text { stereotypes, coordinate and } \\
\text { coherent movements, be } \\
\text { able to complete } \\
\text { movements proficiently } \\
\text { and accurately, have the } \\
\text { ability to observe and } \\
\text { analyze new movements } \\
\text { and imitate, and be able to } \\
\text { apply what they have } \\
\text { learned }\end{array}$ & $\begin{array}{c}\text { Cultivate a good subject } \\
\text { atmosphere, let students } \\
\text { learn to actively discover } \\
\text { and solve problems, } \\
\text { promote sportsmanship, } \\
\text { not be afraid of hardship, } \\
\text { not afraid of tiredness, } \\
\text { and persevere }\end{array}$ \\
\hline
\end{tabular}

In teaching, teachers should choose the best multi-intelligence teaching tools around the teaching content and objectives, not only because some intelligence or some tools in an intelligent field are not suitable for your personality, but also because those tools that seem to be unsuitable for you may well arouse the enthusiasm of students. Even if you choose eight different tools, it doesn't mean that you need to teach in eight steps, and some activities happen at the same time. Multi-teaching toolbox provides a fast and practical teaching method for teaching, as shown in Table 2.

Gardner believes that everyone is unique and is born with a combination of multiple intelligences to highlight one or two intelligences. After proper education, students' intelligence can be maximized. This is the ultimate goal of teaching. In teaching, through the teacher's observation ability, help students to clearly find their strengths and weaknesses as quickly as possible, learn from each other's strengths, and discover their strengths in time, to help students establish the best intelligent learning model under the guidance of the teacher. Intelligent education with students as the main body is shown in Figure 1. 


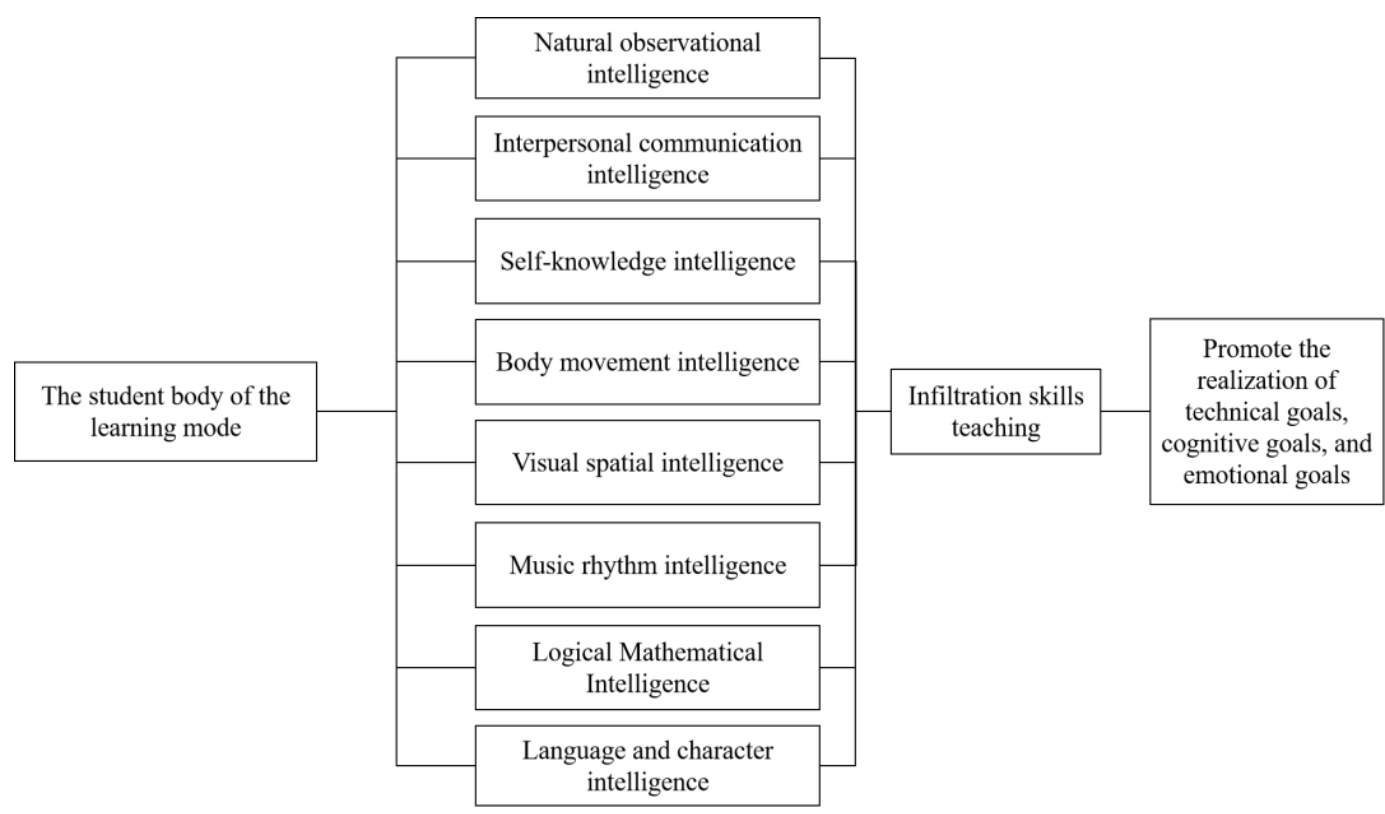

Figure 1. Subjective learning model

Table 2. Features diverse intellectual theory of multiple intelligences and toolbox

\begin{tabular}{|c|c|c|}
\hline Smart type & Intelligent features & Smart Toolbox \\
\hline $\begin{array}{l}\text { Body-Sports } \\
\text { Intelligence }\end{array}$ & $\begin{array}{l}\text { Ability to freely control the body and } \\
\text { have the ability to solve problems, } \\
\text { which is reflected in the coordination, } \\
\text { speed, balance, and other physical skills } \\
\text { of the body }\end{array}$ & $\begin{array}{l}\text { Mastering and practicing various body } \\
\text { movements and motor skills }\end{array}$ \\
\hline $\begin{array}{l}\text { Text-linguistic } \\
\text { intelligence }\end{array}$ & $\begin{array}{l}\text { Effective use of language and speech } \\
\text { for oral and written expression skills }\end{array}$ & $\begin{array}{l}\text { Through physical education theory, } \\
\text { classroom setting questions, the ability } \\
\text { to answer questions, students discuss } \\
\text { with each other, self-summary } \\
\text { evaluation }\end{array}$ \\
\hline $\begin{array}{l}\text { Logic_-Thinking } \\
\text { Intelligence }\end{array}$ & $\begin{array}{l}\text { Ability to accurately use mathematics } \\
\text { and logic for thinking and reasoning. } \\
\text { Thinking and problem-solving in a } \\
\text { logical way }\end{array}$ & $\begin{array}{l}\text { Collect and sort information and data, } \\
\text { organize games, analyze data, logically } \\
\text { demonstrate, and inductive reasoning }\end{array}$ \\
\hline $\begin{array}{l}\text { Visual-spatial } \\
\text { intelligence }\end{array}$ & $\begin{array}{c}\text { Perception of structure, space, color and } \\
\text { shape }\end{array}$ & $\begin{array}{c}\text { Exercise through the control of the } \\
\text { spatial position when the action is } \\
\text { displayed, and use symbols, icons, and } \\
\text { multimedia to learn }\end{array}$ \\
\hline $\begin{array}{l}\text { Music-Rhythm } \\
\text { Intelligence }\end{array}$ & $\begin{array}{l}\text { The ability to appreciate tone, } \\
\text { musicality, and rhythm }\end{array}$ & $\begin{array}{l}\text { Perform various sports with the } \\
\text { accompaniment of music, such as } \\
\text { aerobics, dance, rhythm control during } \\
\text { running, etc. }\end{array}$ \\
\hline $\begin{array}{l}\text { Interpersonal- } \\
\text { Communicative } \\
\text { Intelligence }\end{array}$ & $\begin{array}{l}\text { The ability to communicate normally } \\
\text { with people around }\end{array}$ & $\begin{array}{c}\text { Strengthen the ability to communicate } \\
\text { with others in group competitions } \\
\text { through cooperative learning and } \\
\text { teamwork }\end{array}$ \\
\hline $\begin{array}{l}\text { Self-knowledge } \\
\text { Intelligence }\end{array}$ & $\begin{array}{l}\text { The ability to self-aware and } \\
\text { understand, recognize one's emotions, } \\
\text { motivations, interests and willingness, } \\
\text { be able to observe and reflect on oneself }\end{array}$ & $\begin{array}{l}\text { Correctly understand and evaluate } \\
\text { yourself, find your own strengths and } \\
\text { weaknesses }\end{array}$ \\
\hline $\begin{array}{c}\text { Natural } \\
\text { observational } \\
\text { intelligence }\end{array}$ & $\begin{array}{l}\text { Use instinct, perceive keenly, observe } \\
\text { actively, recognize objects and humans' } \\
\text { ability to perceive nature }\end{array}$ & $\begin{array}{l}\text { Outdoor sports, field survival and other } \\
\text { training }\end{array}$ \\
\hline
\end{tabular}




\subsection{Sports Teaching Reform Inspired by Multiple Intelligences Theory}

Teaching mode is a teaching program with relatively stable teaching process and teaching method system designed according to certain teaching ideas, characteristics of teaching objects, laws of teaching process and teaching conditions The outline advocates that "the change of teaching mode is not only the change of teaching activities or teaching means, but the change of teaching concept." To apply multiple intelligences theory to the process of college physical education, education managers and teachers need to understand relevant theories first. Secondly, in educational practice, students also need to understand relevant educational concepts. Only in this way can we change the learning concept and understand the purpose of teachers' classroom activity design, and improve learning efficiency.

College physical education is a teaching system integrating various teaching modes and teaching methods. Multiple Intelligences Theory tells us that for each teaching content, we can use at least eight different teaching methods to adapt to different students' intelligence tendencies and individualized needs, so that students can master the learning content more easily and effectively. Therefore, college physical education teachers should not only pay attention to physical skills in physical education, but also create and apply other intelligence to participate in learning activities in language teaching, such as music-melody intelligence, interpersonal intelligence and so on.

At present, China is undergoing basic teaching curriculum reform. The new curriculum standards will establish the target system of physical education curriculum as the "curriculum standard" which has been used in China for a long time. The specific performance is four aspects: strengthening physical fitness, mastering and applying basic sports and health knowledge and sports skills. Cultivate sports interests and hobbies, and form the habit of persisting in exercise. Have good psychological qualities, showing the ability of interpersonal communication and the spirit of cooperation. Improve the sense of responsibility for the health of individuals and groups, form a healthy lifestyle, promote sportsmanship, and form a positive, enterprising, optimistic and cheerful attitude towards life. It is logical to use Multiple Intelligences Theory to practice the new curriculum standards, and this theory expands the space and possibilities for the personalized teaching design made by teachers for different students in classroom teaching.

\section{Conclusion}

Multiple intelligences theory is one of the important bases of college physical education curriculum reform. The development of multiple intelligences has realized the diversification of physical education curriculum types. The application of multiple intelligences can promote the transformation of college sports educational concept, accelerate the transformation of college sports educational content, the improvement of educational methods, the transformation of educational subject role, the optimization of educational environment and the improvement of educational evaluation system. Multiple Intelligences Theory creates conditions for individualized teaching, which makes educators understand that education should develop all kinds of intelligence in each person's brain in an all-round way, to stimulate each person's potential intelligence and fully develop each person's personality. The Multiple Intelligences Theory plays a key role in the reform of school physical education. In-depth study of Multiple Intelligences Theory in College sports teaching, making it consistent with the characteristics of college sports teaching, making College sports teaching a position to develop students' multiple intelligences. It is recommended that Multiple Intelligences Theory be widely used in college sports teaching, which will play a positive role in further deepening education reforms in colleges and universities, improving the teaching quality of courses, and cultivating high-quality and strong-capable comprehensive talents required by the times. Multiple Intelligences Theory, guided by respecting educational concepts, meets the basic requirements of modern teaching theory. Its experimental research starts from the characteristics of the times and students, and provides theoretical and practical basis for a new round of new curriculum reform. 
Volume 3 (2021)

\section{References}

[1] Wang Lan. Research on the New Concept of College Sports Teaching Based on Multiple Intelligences Theory [J]. Contemporary Sports Science and Technology, 2016, 6(021):4-5.

[2] Lu Jinyu. Application and suggestion of Multiple Intelligences Theory in physical education[J]. Journal of Military Sports, 2017, 36(001):87-90.

[3] Chen Jinbo. College sports curriculum reform based on Multiple Intelligences Theory [J]. Contemporary Sports Science and Technology, 2016, 6(009):71-72.

[4] Shi Lu, Wang Shuo. New Enlightenment of Multiple Intelligences Theory to College Sports Teaching[J]. Fujian Tea, 2019, v.41; No.210(06):140-142.

[5] Peng Chengcai, Huang Zhaowei. The Enlightenment of Howard Gardner's Multiple Intelligences Theory on the Teaching of National Aerobics Courses in Colleges and Universities [J]. University Education, 2020, 000(006): 130-132.

[6] Zheng Yin. Research on the Reform Strategy of University Track and Field Teaching Mode under Multiple Intelligences Theory[J]. Sports Fashion, 2017, 000(002):17-18.

[7] Wang Le. Research on Teaching Reform of College Aerobics Based on Multiple Intelligences Theory[J]. Contemporary Sports Science and Technology, 2017, 7(027):118-119.

[8] Xu Gang. Building a "four-in-one" college sports talent training model based on Multiple Intelligences Theory [J]. Stationery \& Sports Supplies \& Technology, 2020, No.438(05):121-122. 